\title{
Preparation of Biodegradable Mg/ $\beta$-TCP Biofunctional Gradient Materials by Friction Stir Processing and Pulse Reverse Current Electrodeposition
}

\author{
Yabo Zhang ${ }^{1}$ - Huiling Yang ${ }^{1}$ - Shaoqian Lei ${ }^{1}$. Shijie Zhu ${ }^{1,2}$ - Jianfeng Wang ${ }^{1,2}$ - Yufeng Sun ${ }^{1,2}$. Shaokang Guan ${ }^{1,2}$
}

Received: 10 April 2019 / Revised: 18 July 2019 / Published online: 19 October 2019

(C) The Chinese Society for Metals (CSM) and Springer-Verlag GmbH Germany, part of Springer Nature 2019

\begin{abstract}
Mg alloys, as a new generation of biodegradable bone implant materials, are facing two tremendous challenges of enhancing strength and reducing degradation rate in physiological environment to meet clinical needs. In this study, tricalcium phosphate ( $\beta$-TCP) particles were dispersed in $\mathrm{Mg}-2 \mathrm{Zn}-0.46 \mathrm{Y}-0.5 \mathrm{Nd}$ alloy by friction stir processing (FSP) to produce $\mathrm{Mg}$-based functional gradient materials (Mg/ $\beta$-TCP FGM). On the surface of Mg/ $\beta$-TCP FGM, the hydroxyapatite (HA) coating was prepared by electrodeposition. The effects of FSP and electrochemical parameter on the microstructure, microhardness, bonding strength and corrosion performance of the Mg/ $\beta$-TCP FGM were investigated. After four passes of FSP, a uniform and fine-grained structure was formed in $\mathrm{Mg} / \beta-\mathrm{TCP}$ and the microhardness increased from 47.9 to $76.3 \mathrm{HV}$. Compared to the samples without $\beta$-TCP, the bonding strength of the Mg/ $\beta$-TCP FGM increased from $23.1 \pm 0.462$ to $26.3 \pm 0.526 \mathrm{MPa}$ and the addition of degradable $\beta$-TCP contributed to the in situ growth of HA coating. The thickness of HA coating could be dominated by controlling the parameters of electrodeposition. According to the results of immersion tests and electrochemical tests in simulated body fluid, it indicated that the degradation rate of the Mg/ $\beta$-TCP FGM could be adjusted.
\end{abstract}

Keywords Biodegradable magnesium alloy $\cdot$ Biofunctional gradient materials $\cdot$ Friction stir processing $\cdot$ Tricalcium phosphate $(\beta-\mathrm{TCP}) \cdot$ Electrodeposition

\section{Introduction}

$\mathrm{Mg}$ alloys, as a new class of metallic bone implant materials, show excellent performance compared to Ti alloys, stainless steels, ceramics, etc. [1-4]. The density $\left(1.74 \mathrm{~g} / \mathrm{cm}^{3}\right)$ and Young's modulus ( $40 \mathrm{GPa}$ ) of Mg alloys are comparable to those of bone and can effectively reduce an extra pain caused by the stress shielding [1, 3, 5-7]. Their good biocompatibility, biodegradability and biological activity can avoid secondary surgery and promote bone cell proliferation, which

Available online at http://link.springer.com/journal/40195

Shijie Zhu

zhusj@zzu.edu.cn

Shaokang Guan

skguan@zzu.edu.cn

1 School of Materials Science and Engineering, Zhengzhou University, Zhengzhou 450001, China

2 Henan Key Laboratory of Advanced Magnesium Alloys, Zhengzhou 450002, China attract extensive attention and research of $\mathrm{Mg}$ alloys [3, 4, 6]. However, Mg alloys have a very active electrochemical property and are corroded easily in chlorine-ion-bearing solution like the physiological environment of the human body, which significantly limits their clinical applications [7-9].

A number of related studies show that severe plastic deformation and surface treatment are the relatively effective methods to improve the corrosion resistance of $\mathrm{Mg}$ alloys $[10,11]$. Friction stir processing (FSP) is a thermomechanical processing technique. During FSP, microstructures are modified by plastic deformation and subsequent dynamic recrystallization [10, 12-18]. However, the application of FSP in Mg alloys mainly results in grain refinement and redistribution of second phases [19]. The principle behind the grain refinement, dynamic recrystallization due to intense plastic deformation within the stir zone, has been explored and explained by Mishra et al. [20]. Previous researches show that the corrosion resistance of $\mathrm{Mg}$ alloys increases with grain refinement, owing to the grain boundaries acting as barriers to retard the corrosion process 
$[21,22]$. Therefore, fabrication of $\mathrm{Mg}$ alloys with refined grain structure is a very important way to enhance corrosion resistance.

In addition, Mg-based composites produced by FSP show slow corrosion rate and are widely used in engineering and biomedical fields [23-25]. For example, Sunil et al. incorporate hydroxyapatite (HA) in Mg alloy by FSP and the results show that the $\mathrm{Mg} / \mathrm{HA}$ metal matrix nanocomposite has good bioactivity and low corrosion rate [26, 27]. The nanohydroxyapatite (nHA) particles in the AZ31-nHA composite initiate heterogeneous nucleation which favors the preferential nucleation and the growth of calcium phosphate mineral phase [26]. The tricalcium phosphate ( $\beta$-TCP) is ubiquitous in human bones and has many advantages as a bone repair material, such as the good bone conduction, good biocompatibility and osteoinductive activity [28, 29]. $\mathrm{Mg}-2 \mathrm{Zn}-0.46 \mathrm{Y}-0.5 \mathrm{Nd}$ is a suitable biodegradable material with superior mechanical properties and corrosion resistance [30]. The $\mathrm{Mg} / \beta$-TCP composite can be prepared by dispersing $\beta$-TCP into the as-cast $\mathrm{Mg}-2 \mathrm{Zn}-0.46 \mathrm{Y}-0.5 \mathrm{Nd}$ after FSP.

During healing of bone tissue, the implanted $\mathrm{Mg}$ alloys or Mg-based composites present in the body and maintain mechanical integrity for 12-18 weeks, and then eventually are replaced by natural tissue $[4,31]$. It is very essential to regulate the degradation rate of $\mathrm{Mg}$ alloys. Functional gradient materials (FGMs) originating in Japan in 1989 during the space plan project (FGM dental implant material) are expected to achieve precise control of the corrosion rate [32]. The degradable bone implanted FGM can be obtained to reduce degradation rate by biocoating on the surface of $\mathrm{Mg}$ matrix composite. The study by Hanas et al. [33] indicates that a gradient material with good biodegradation and biomineralization is obtained by forming a coating of electrospun nanofibrous polycaprolactone/HA (PCL/HA) on the surface of FSPed AZ31/HA composite.

Recently, surface modification, such as chemical conversion coatings, electrochemical deposition and microarc oxidation (MAO), has been regarded as a convenient and feasible method to improve corrosion resistance and adjust degradation rate of the substrate materials [11, 33-35]. Electrochemical deposition has unique advantages due to its capability of forming a uniform coating on a substrate with complex surface shape and its controllability with regard to the thickness and chemical composition of the coating [36]. Compared to other electrodeposition modes, pulse reverse current (PRC) is more suitable to prepare a denser and higher-crystallinity HA coating on surface of Mg alloys or Mg-based composites [37, 38].

In this study, $\mathrm{Mg} / \beta$-TCP FGM was prepared by FSP and PRC electrodeposition with the purpose of adjusting the degradation rate for the clinical application of magnesium alloy bone implantation. The $\beta$-TCP particles were dispersed on the surface of the Mg-2Zn-0.46Y-0.5Nd alloy by FSP to obtain a Mg/ $\beta$-TCP composite layer. Then, the HA coatings with different thicknesses were formed on the $\mathrm{Mg} / \beta$-TCP composite layer by PRC. The $\beta$-TCP of FSPed layer has a double role: (1) refining grains and (2) contributing to the in situ growth of the HA coating to improve the bonding strength. Moreover, the in vitro degradation behaviors of annealed $\mathrm{Mg}-2 \mathrm{Zn}-0.46 \mathrm{Y}-0.5 \mathrm{Nd}, \mathrm{Mg} / \beta-\mathrm{TCP}$ composite and different $\mathrm{Mg} / \beta$-TCP FGM in simulated body fluid (SBF) were also compared. The final results indicate that $\mathrm{Mg} / \beta$-TCP FGM is a potential biodegradable bone implant material with good mechanical properties and degradation rate adjustability.

\section{Experimental}

\subsection{Materials}

The as-cast $\mathrm{Mg}-2 \mathrm{Zn}-0.46 \mathrm{Y}-0.5 \mathrm{Nd}$ was subjected to homogenization annealing at $430{ }^{\circ} \mathrm{C}$ for $72 \mathrm{~h}$ and then cut into sheets with a dimension of $200 \mathrm{~mm} \times 80 \mathrm{~mm} \times 8 \mathrm{~mm}$. The surface of the sheets was cleaned and polished to remove any debris and contamination. The $99 \%$ purity spherical $\beta$-TCP particles of $0.5 \mu \mathrm{m}$ were provided by Nanjing Epure Nano Materials Company. Holes were drilled on the $\mathrm{Mg}$ alloy sheets to fill the $\beta$-TCP particles. The number and distribution of the holes shown in Fig. 1a were designed and optimized on the $\mathrm{Mg}$ alloy sheets according to the length of stir pin and shoulder width.
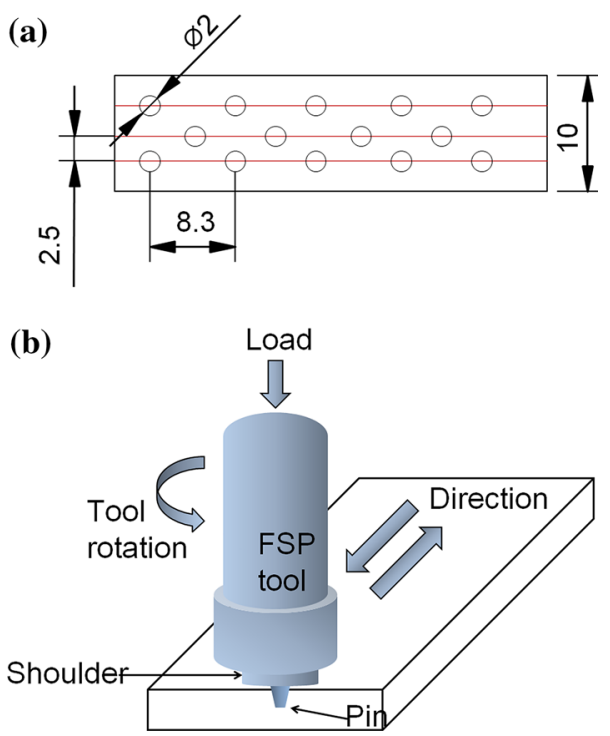

Fig. 1 Preset diagram of $\beta$-TCP (mm) a, schematic of FSP b 


\subsection{Friction stir processing}

Friction stir processing was conducted on FSW-LM-AM162D gantry friction stir welding machine. The pin of the stirring tool had a length of $3 \mathrm{~mm}$, and the root diameter of the pin was $4.2 \mathrm{~mm}$ and the end diameter was $3 \mathrm{~mm}$. The stir tool had a concave shoulder with a diameter of $10 \mathrm{~mm}$. The tool rotation rate, tool traverse speed, plunge depth and inclination of the shoulder were $1500 \mathrm{rpm}, 25 \mathrm{~mm} / \mathrm{min}, 0.15 \mathrm{~mm}$ and $2.5^{\circ}$, respectively. When the FSP was repeated with $n$ passes, it was named as FSP- $n$ and the obtained composite was defined as Mg/ $\beta$-TCP $(+$ FSP- $n$ ). The schematic of FSP is presented in Fig. $1 \mathrm{~b}$.

\subsection{Microstructure characterization}

The samples with a dimension of $10 \mathrm{~mm} \times 10 \mathrm{~mm} \times 8 \mathrm{~mm}$ were cut from the stir zone and then grounded with $\mathrm{SiC}$ papers up to 1000 grit, ultrasonically cleaned in ethanol and finally dried. The polished surface was etched with picric acid (a mixture of $2.1 \mathrm{~g}$ picric acid, $10 \mathrm{ml}$ acetic acid, $70 \mathrm{ml}$ ethyl alcohol and $20 \mathrm{ml}$ distilled water) for microstructural observation. Microstructures of the homogenizing annealed alloy and FSP- $n$ specimens were observed by a Leica DM4000M optical microscope (OM). The microstructure and element distribution of FSP-4 sample were identified by a FEI Quanta-2000 scanning electron microscope (SEM) equipped with an energy-dispersive spectroscope (EDS) at an accelerating voltage of $20 \mathrm{kV}$.

\subsection{Electrochemical deposition}

In the PRC mode, HA coating was prepared on the surface of the $\mathrm{Mg} / \beta$-TCP composite using an electrochemical workstation (RST5200F) to produce $\mathrm{Mg} / \beta$-TCP FGM. The schematic of Mg/ $\beta$-TCP FGM is shown in Fig. 2. The electrolytes

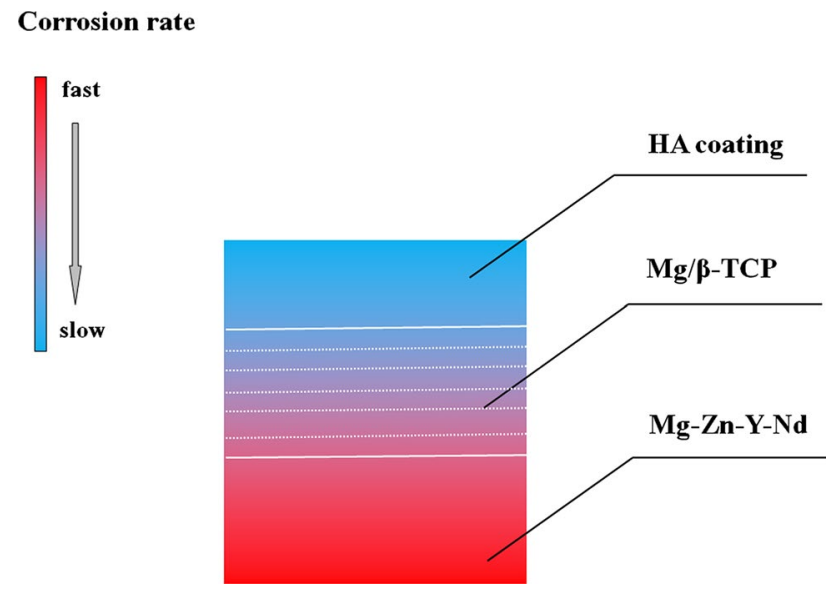

Fig. 2 Schematic of Mg/ $\beta$-TCP FGM used for generating calcium phosphate deposits were a solution mixed in the order of $2.48 \mathrm{~g} / \mathrm{L} \mathrm{Ca}\left(\mathrm{NO}_{3}\right)_{2} \cdot 4\left(\mathrm{H}_{2} \mathrm{O}\right)$, $8.5 \mathrm{~g} / \mathrm{L} \mathrm{NaNO}_{3}, 0.72 \mathrm{~g} / \mathrm{L} \mathrm{NH}_{4} \mathrm{H}_{2} \mathrm{PO}_{4}$ and $10 \mathrm{ml} / \mathrm{L} \mathrm{H}_{2} \mathrm{O}_{2}$. During the electrodeposition, a rectangular $\mathrm{Mg} / \beta-\mathrm{TCP}$ composite sample $(10 \mathrm{~mm} \times 10 \mathrm{~mm} \times 8 \mathrm{~mm})$ was used as the working electrode and a graphite plate was served as the counter electrode. The electrodeposition treatment solution was heated to $80^{\circ} \mathrm{C}$, the current density was set as $0.1 \mathrm{~mA} /$ $\mathrm{cm}^{2}$ and $10 \mathrm{~mA} / \mathrm{cm}^{2}$, and the deposition time was varied as $5 \mathrm{~s}, 15 \mathrm{~s}, 1 \mathrm{~min}, 5 \mathrm{~min}, 15 \mathrm{~min}$ and $30 \mathrm{~min}$, respectively. After the electrodeposition, the sample was taken out of the solution, rinsed three times using distilled water and dried in an oven. The morphology and elemental composition of the HA coating after electrodeposition were characterized by SEM and EDS.

\subsection{Mechanical properties}

Vickers microhardness of processed materials was measured using a HXD-1000TMSC/LCD digital microhardness tester at a load of $100 \mathrm{~g}$ with a dwell time of $15 \mathrm{~s}$. The sample was taken from the middle of FSP sheets along the transverse direction. Series of points were selected to measure microhardness at an interval of $0.5 \mathrm{~mm}$ along the midline of FSPed sample. The bonding strength between the electrodeposited coating and $\mathrm{Mg}$ alloy substrate was measured using a Hitachi AG-IS universal testing machine at a crosshead rate of $1 \mathrm{~mm} / \mathrm{min}$. Figure 3 shows the test process. The coated sample and the Mg-based matrix material were

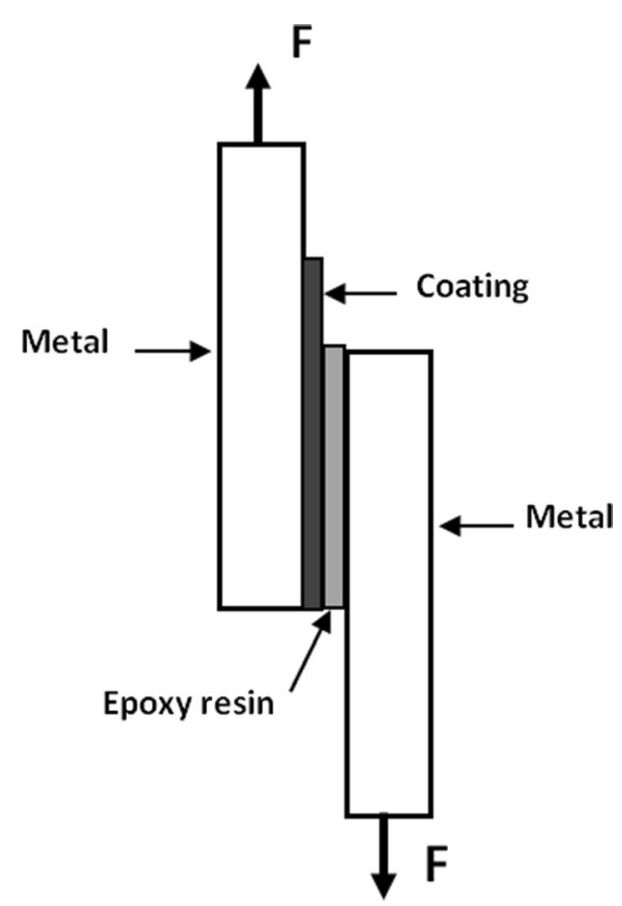

Fig. 3 Schematic diagram of the bonding strength test 
adhered together by epoxy resin, and the bonding area was $1 \mathrm{~cm}^{2}$. Then the adhered sample was fixed with a transparent tape and placed in a heat treatment furnace at $100{ }^{\circ} \mathrm{C}$ for $3 \mathrm{~h}$. And finally the tensile tests were performed. At least three parallel specimens were tested for each condition.

\subsection{Corrosion evaluations}

Corrosion behavior of the $\mathrm{Mg} / \beta-\mathrm{TCP}+\mathrm{FSP}-4$, annealed $\mathrm{Mg}-2 \mathrm{Zn}-0.46 \mathrm{Y}-0.5 \mathrm{Nd}$ and $\mathrm{Mg} / \mathrm{\beta}-\mathrm{TCP}$ FGM specimens in the SBF was investigated by mass loss, dynamic potential polarization measurement and electrochemical impedance spectroscopy (EIS). The composition and preparation procedure of SBF solution are listed in Table 1. Samples for corrosion evaluations were completely sealed with epoxy resin except an exposed area of $1 \mathrm{~cm}^{2}$. The electrochemical measurements were taken in a three-electrode cell, in which a platinum counter electrode and a saturated calomel reference electrode were used. The polarization tests were carried out at a potential sweep rate of $1 \mathrm{mV} / \mathrm{s}$. The ac frequency ranged from $10^{5}$ to $10^{-2} \mathrm{~Hz}$ with a sampling step of 12 points per decade. The polarization amplitude was $10 \mathrm{mV}$ around the open-circuit potential (OCP). Three electrochemical tests were performed for each testing condition. The samples were immersed in SBF at $37^{\circ} \mathrm{C}$ for 14 days or 12 days. In order to keep the solution fresh, the solution was replaced every day. Then, the immersed samples were placed in chromic acid solution to remove the corrosion production and ultrasonically cleaned for $5 \mathrm{~min}$. Assuming a uniform corrosion rate, the corrosion rate was calculated using the following equation:

$V=r W /(S \cdot T)$,

where $V$ is the corrosion rate $\left[\mathrm{mg} /\left(\mathrm{cm}^{2} \mathrm{~h}\right)\right], \Delta W$ is the mass loss (mg), $S$ is the exposed area $\left(\mathrm{cm}^{2}\right)$ and $T$ is the time of immersion (h).

Meanwhile, the morphology and the composition of the corrosion products were analyzed by SEM and EDS, respectively.

\section{Results and discussion}

\subsection{Microstructures}

Figure 4a shows that the grain boundary segregation is eliminated and the second phase is dissolved into the matrix to obtain a uniform structure after homogenizing annealing.

Table 1 Amount of reagents for preparing $1000 \mathrm{ml}$ of the $\mathrm{SBF}$

\begin{tabular}{lllllllll}
\hline $\mathrm{NaCl}$ & $\mathrm{NaHCO}_{3}$ & $\mathrm{KCl}$ & $\mathrm{K}_{2} \mathrm{HPO}_{4} \cdot 3 \mathrm{H}_{2} \mathrm{O}$ & $\mathrm{MgCl}_{2} \cdot 6 \mathrm{H}_{2} \mathrm{O}$ & $\mathrm{HCl}$ & $\mathrm{CaCl}_{2}$ & $\mathrm{Na}_{2} \mathrm{SO}_{4}$ & Tris \\
\hline $8.035 \mathrm{~g}$ & $0.355 \mathrm{~g}$ & $0.225 \mathrm{~g}$ & $0.231 \mathrm{~g}$ & $0.311 \mathrm{~g}$ & $39 \mathrm{ml}$ & $0.292 \mathrm{~g}$ & $0.072 \mathrm{~g}$ & $6.118 \mathrm{~g}$
\end{tabular}
solution
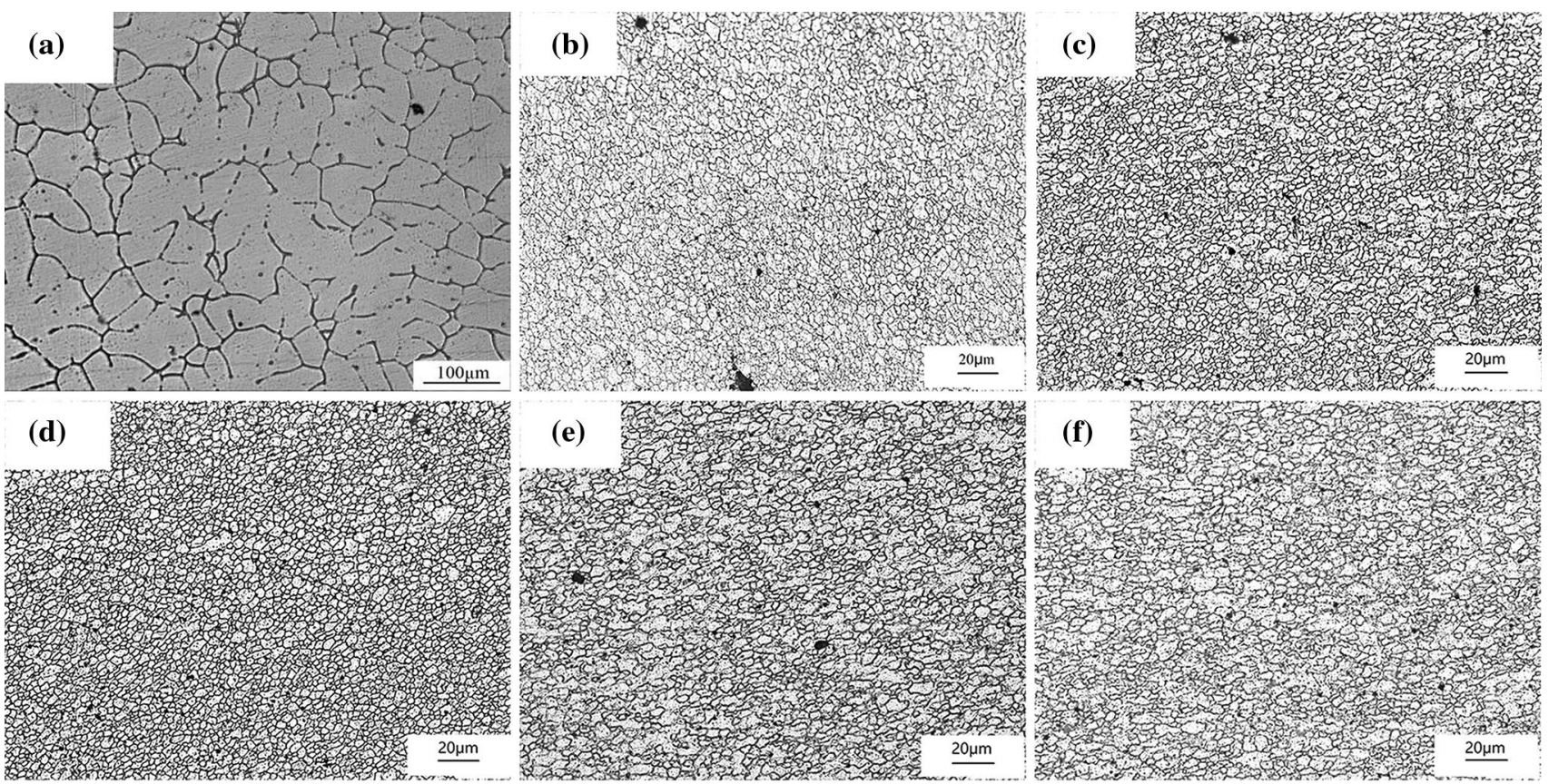

Fig. 4 OM images of as-cast Mg-Zn-Y-Nd and Mg/B-TCP: a annealed Mg-2Zn-0.46Y-0.5Nd; b FSP-1; c FSP-3; d FSP-4; e FSP-5; f FSP-6 
It is worth noting that the grain size after homogenizing annealing increases significantly. The optical microstructure of the $\mathrm{Mg} / \beta$-TCP samples subjected to various FSP passes is shown in Fig. 4. The FSP mainly affects the grain structure evolution, especially in the stir zone (SZ), where material is affected by both heat and large deformation. It is known that the grain structure evolution in the SZ is a very complex process and is driven mainly by continuous dynamic recrystallization (CDRX) and geometric dynamic recrystallization (GDRX) [39-42]. After FSP-4, the grains become fine and uniform and the average grain size is about $2.0 \mu \mathrm{m}$. The average grain sizes of FSP-1, FSP-3, FSP-5 and FSP-6 are $3.5 \mu \mathrm{m}, 3 \mu \mathrm{m}, 4 \mu \mathrm{m}$ and $5 \mu \mathrm{m}$, respectively. Compared to the grains in Fig. 4b-d, the grains in Fig. 4e, f are lager and elongated. From the perspective of dynamic recrystallization, FSP-1 and FSP-3 experience insufficient heat input and deformation to obtain uniform structure, and the FSP-5 and FSP-6 experience too much heat input for the grains growth [18, 40, 42].

As shown in Fig. 5, the corresponding EDS analysis clearly indicates the presence of $\mathrm{Ca}$ and $\mathrm{P}$ elements and $\beta$-TCP in the $\mathrm{Mg}-2 \mathrm{Zn}-0.46 \mathrm{Y}-0.5 \mathrm{Nd}$ alloy matrix. The dispersed $\beta$-TCP (Fig. 5) exists mainly on the grain boundaries, implying the uniform dispersion of $\beta$-TCP in the $\mathrm{Mg} / \beta$-TCP by FSP-4. Furthermore, the presence of $\beta$-TCP particles improves the bioactivity and refines the grains acting as the heterogeneous nucleation sites [28-39].

\subsection{Mechanical properties}

The measured microhardness of $\mathrm{Mg} / \beta$-TCP is summarized in Fig. 6. After FSP, three specific zones can be observed in the processing area: (a) SZ, (b) thermo-mechanically affected

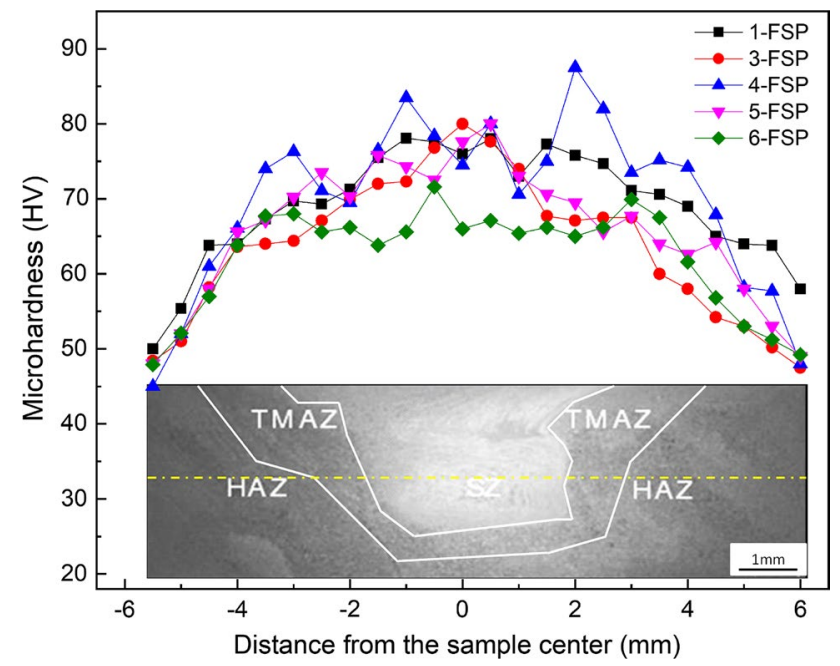

Fig. 6 Microhardness curve and cross-sectional structure of $\mathrm{Mg} / \beta$ TCP composite by FSP- $n$; test points along yellow dotted line

zone (TMAZ) and (c) heat-affected zone (HAZ). The results of the microhardness tests show that the SZ has the maximum hardness and the hardness gradually decreases in the area away from the SZ. The hardness curve of the FSP-4 sample is at the top and has a higher hardness peak with a larger width, compared with other FSPed samples.

The hardness of the $\mathrm{Mg} / \mathrm{\beta}-\mathrm{TCP}$ composite (average 76.3 $\mathrm{HV}$ ) is much higher than that of the annealed $\mathrm{Mg}-\mathrm{Zn}-\mathrm{Y}-\mathrm{Nd}$ (average $47.9 \mathrm{HV}$ ). The microstructure in the $\mathrm{SZ}$ is fine and equiaxed, which is caused mainly by CDRX and GDRX. However, in the TMAZ and HAZ, the grains are relatively coarser than those in the SZ due to the partially occurred DRX or normal grain growth [18]. And the microhardness
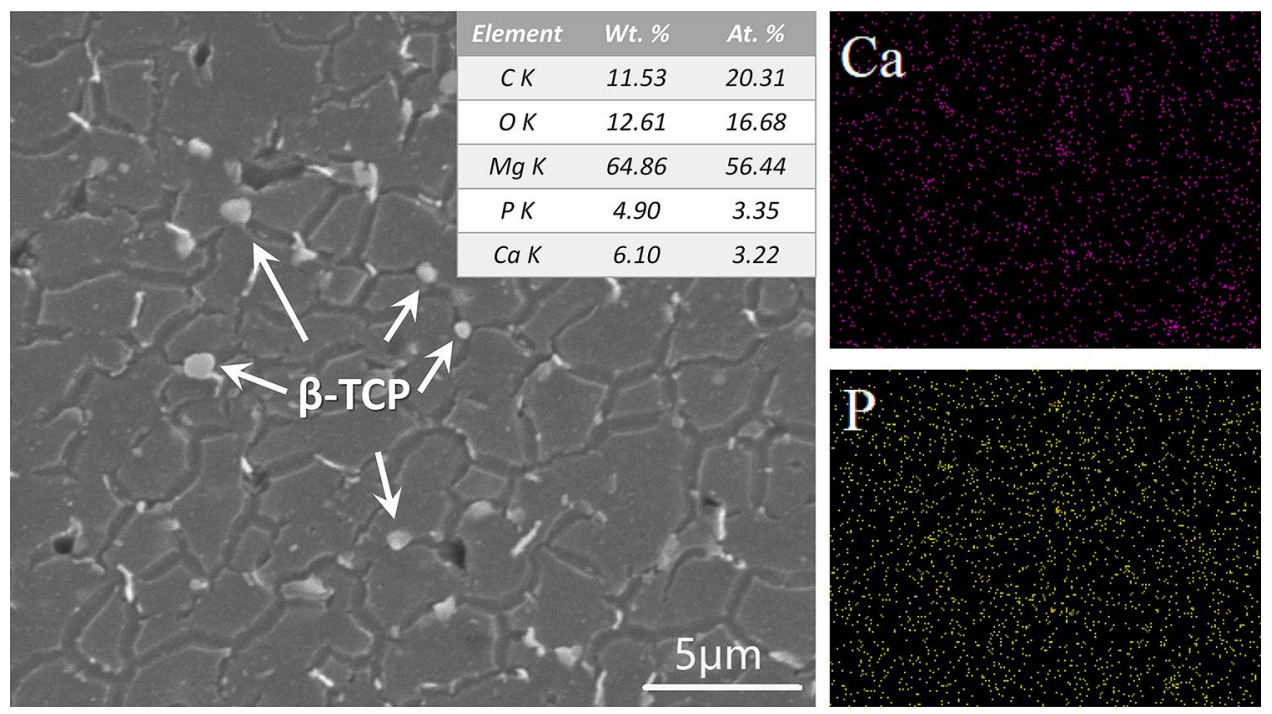

Fig. 5 SEM image and EDS mapping of Mg/ $\beta$-TCP composite by FSP-4 
of $\mathrm{Mg} / \beta$-TCP is related to the microstructure subjected to temperature and strain generated by FSP- $n$. The finegrained strengthening and dispersion strengthening caused by the $\beta-\mathrm{TCP}$ in $\mathrm{Mg} / \beta-\mathrm{TCP}$ are supposed to contribute to the increase in the hardness.

HA coatings are prepared on the FSP- 4 and annealed samples via electrodeposition method. The results indicate that bonding strength of the $\mathrm{Mg} / \beta-\mathrm{TCP}-\mathrm{HA}$ coating is $26.3 \pm 0.526 \mathrm{MPa}$, while that of the $\mathrm{Mg}-\mathrm{HA}$ coating is $23.1 \pm 0.462 \mathrm{MPa}$. The addition of $\beta$-TCP increases the bonding strength between coating and substrate. This is because that the $\beta$-TCP has the same hexagonal structure as HA. The presence of $\beta$-TCP reduces the discontinuity of the coefficient of thermal expansion between the coating and the matrix. Therefore, the bonding strength can be increased [13].

\subsection{Electrochemical measurements}

The results of electrochemical tests for the three kinds of samples are shown in Fig. 7 and Table 2. Table 2 lists that the current density of the $\mathrm{Mg} / \beta$-TCP FGM is decreased by an order of magnitude compared to those of the annealed $\mathrm{Mg}-2 \mathrm{Zn}-0.46 \mathrm{Y}-0.5 \mathrm{Nd}$ and $\mathrm{Mg} / \beta-\mathrm{TCP}+\mathrm{FSP}-4$. And the opposite variation trend between corrosion potential and current of annealed $\mathrm{Mg}-2 \mathrm{Zn}-0.46 \mathrm{Y}-0.5 \mathrm{Nd}$ and $\mathrm{Mg} / \beta-$ TCP + FSP-4 is listed in Table 2, which may be due to the $\beta$-TCP as cathodic protection. The diameter of the capacitive loop is associated with the polarization resistance, and the large ones indicate the slow electrochemical process. Figure $7 \mathrm{~b}$ reveals that the polarization resistance of the $\mathrm{Mg} / \beta$ TCP FGM is the largest. This is confirmed by the lowest current density of the $\mathrm{Mg} / \beta$-TCP FGM. During the immersion in $\mathrm{SBF}$, the $\mathrm{Ca}-\mathrm{P}$ corrosion products of $\mathrm{Mg}$ alloys, which have the same elements as $\beta$-TCP, slow down the
Table 2 Electrochemical data for the experimental samples in SBF solution derived from the polarization curves

\begin{tabular}{lll}
\hline Sample state & $E_{\text {corr }}(\mathrm{V})$ & $i_{\text {corr }}\left(\mathrm{A} \mathrm{cm}^{-2}\right)$ \\
\hline Annealed Mg-2Zn-0.46Y- & -1.590 & $9.65 \times 10^{-4}$ \\
$0.5 \mathrm{Nd}$ & & \\
$\mathrm{Mg} / \beta$-TCP + FSP-4 & -1.671 & $1.07 \times 10^{-4}$ \\
$\mathrm{Mg} / \beta$-TCP FGM & -1.575 & $1.57 \times 10^{-5}$ \\
\hline
\end{tabular}

corrosion rate $[4,6]$. There are two reasons why the impedance of $\mathrm{Mg} / \mathrm{\beta}-\mathrm{TCP}+\mathrm{FSP}-4$ is more than that of the annealed $\mathrm{Mg}-2 \mathrm{Zn}-0.46 \mathrm{Y}-0.5 \mathrm{Nd}$ as shown in Fig. $7 \mathrm{~b}$ : (1) the refinement of the grains and (2) $\beta$-TCP as cathodic protection possibly. It is revealed that the order of corrosion resistance is as follows: $\mathrm{Mg} / \beta$-TCP FGM $>\mathrm{Mg} / \beta-\mathrm{TCP}+\mathrm{FSP}-4>$ annealed $\mathrm{Mg}-2 \mathrm{Zn}-0.46 \mathrm{Y}-0.5 \mathrm{Nd}$.

\subsection{Microstructure and composition of the $\mathrm{Ca}-\mathrm{P}$ coating}

According to Fig. 8a, the agglomeration of $\beta$-TCP by FSP-1 is easily formed, which helps to observe better the growth of the coating in the early stage. As shown in Fig. 8, the coating on the surface of the sample grows into a needlelike form and gradually covers the entire surface. With the electrodeposition time extended, the HA coating at the $\beta$-TCP region gradually grows into a flower shape from a bud shape. Figure 9 shows that the $\mathrm{P}$ and $\mathrm{Ca}$ contents in area 1 are increased by $9.82 \%$ and $8.21 \%$ after $5 \mathrm{~min}$, while in area 2 they are increased by $7.17 \%$ and $4.65 \%$. The result indicates that the growth rate of $\mathrm{Ca}$ and $\mathrm{P}$ content in area 1 is faster than that in area 2.

Figures 8 and 9 show that the addition of $\beta$-TCP promotes the nucleation of HA and in situ growth of the (a)

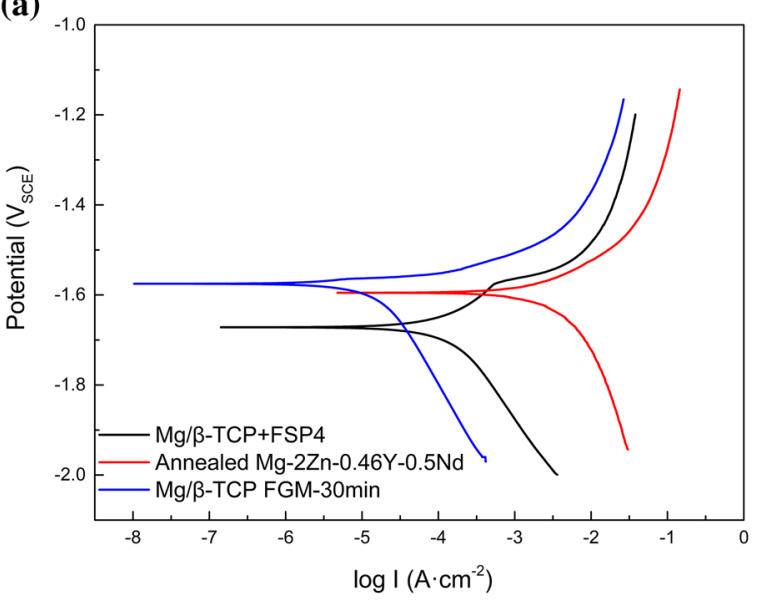

(b)

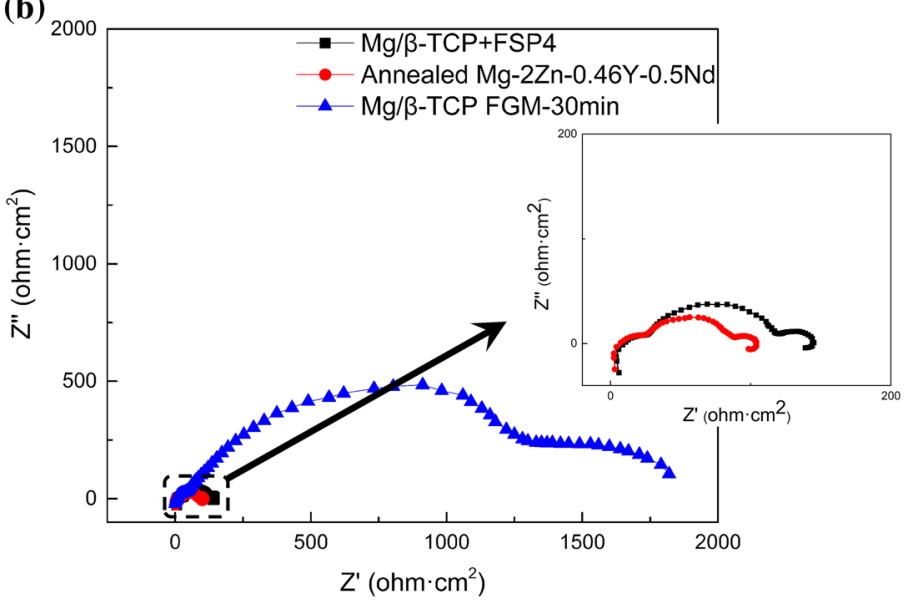

Fig. 7 Electrochemical test results of the experimental samples in SBF solution: a polarization curves; b Nyquist plots 

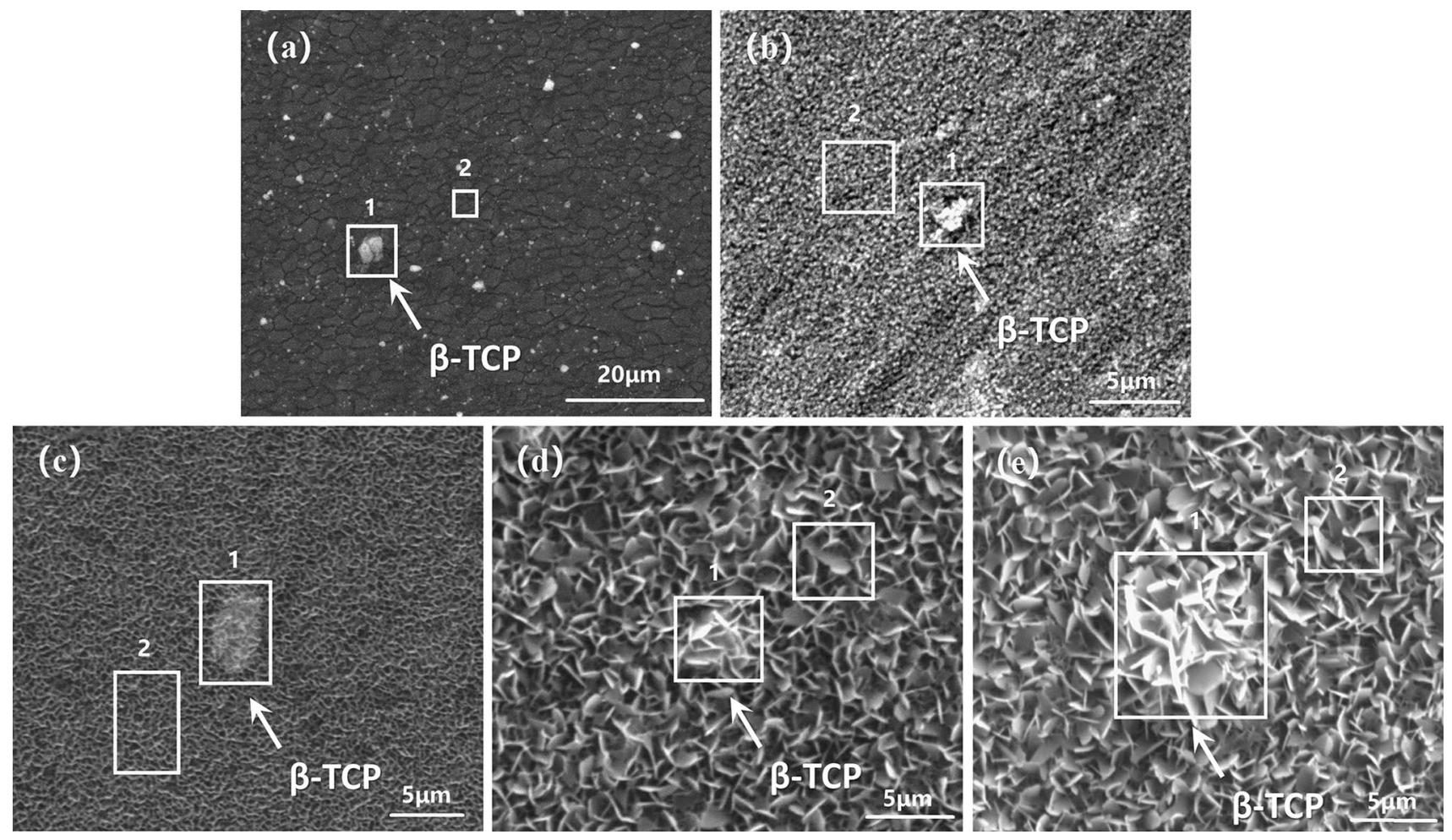

Fig. 8 SEM images of the coatings on Mg/ $\beta$-TCP by FSP-1 deposited at $0.1 \mathrm{~mA} / \mathrm{cm}^{2}$ with $0 \mathrm{~s}$ a, $5 \mathrm{~s} \mathrm{~b}, 15 \mathrm{~s}$ c, $60 \mathrm{~s}$ d, $300 \mathrm{~s}$ e, respectively; regions 1 and 2 represent the presence of $\beta$-TCP and the absence of $\beta$-TCP
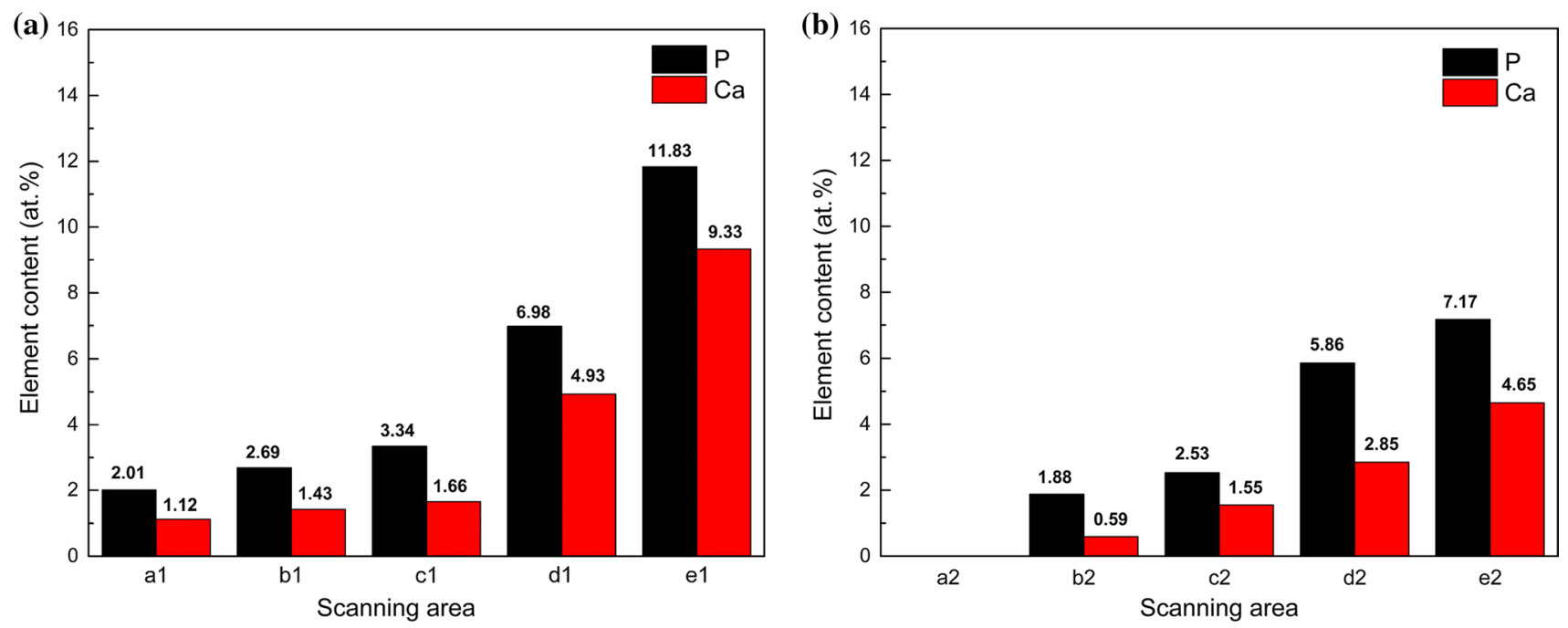

Fig. 9 Element contents of $\mathrm{P}$ and Ca distributed in area $1 \mathbf{a}, 2$ b in Fig. 8

coating [34]. In order to obtain flat and uniform coating, the $\mathrm{Mg} / \beta$-TCP + FSP- 4 is selected as the substrate for electrodeposition, and the current density is selected to be $10 \mathrm{~mA} / \mathrm{cm}^{2}$. In addition, it is worth noting that the thickness of the coating obtained can be controlled by the current density and deposition time [43, 44].
As shown in Fig. 10, the thickness of HA coating is uniform, indicating a relatively uniform dispersion of $\beta$-TCP in $\mathrm{Mg} / \beta-\mathrm{TCP}+\mathrm{FSP}-4$. The liner element distribution curves of $\mathrm{Mg} / \beta$-TCP FGM indicate that with a deposition time of $5 \mathrm{~min}, 15 \mathrm{~min}$ and $30 \mathrm{~min}$, a coating thicknesses of $3 \mu \mathrm{m}$, $5 \mu \mathrm{m}$ and $9 \mu \mathrm{m}$ can be obtained accordingly. As a result, the 

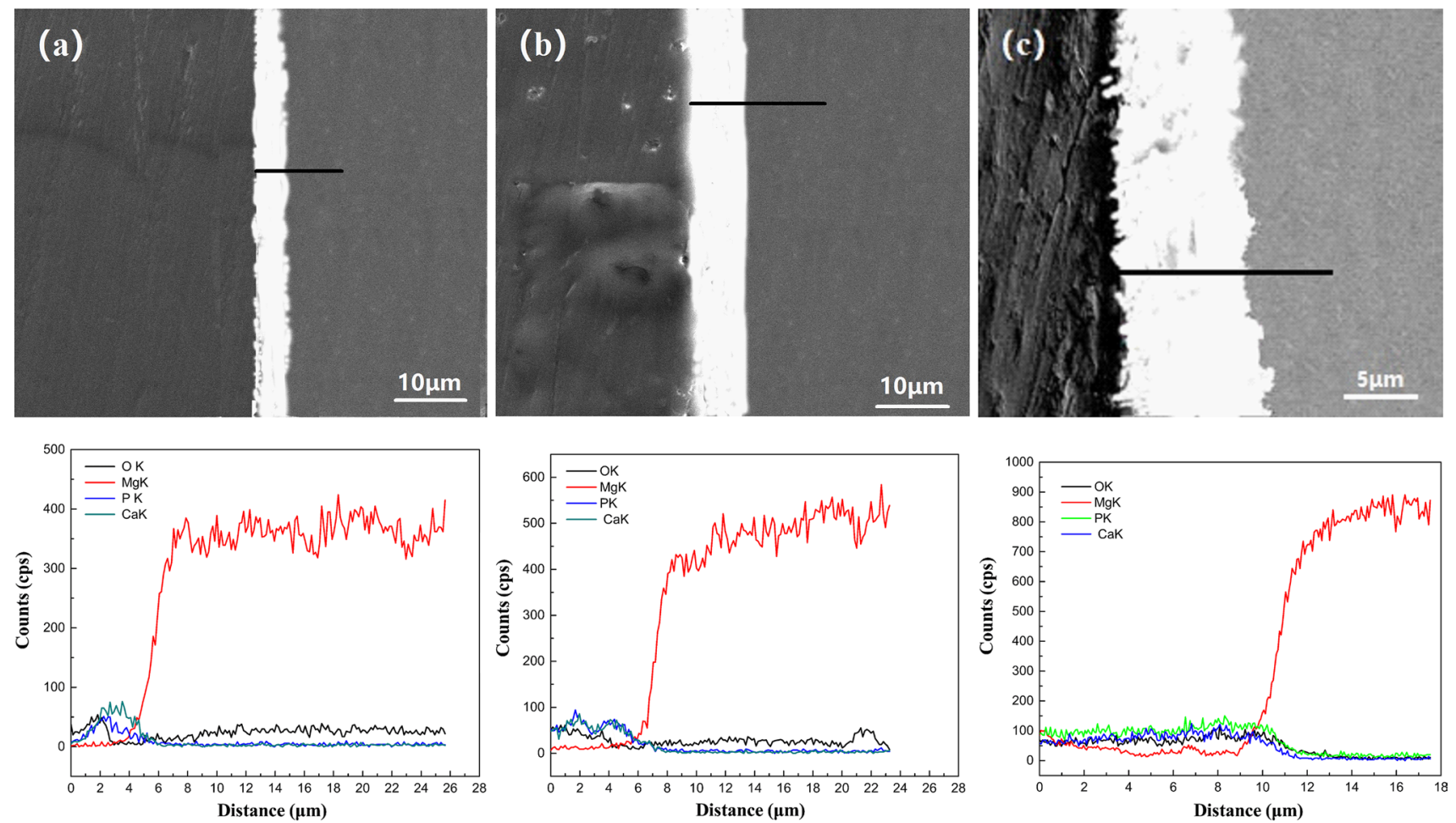

Fig. 10 Cross-sectional morphologies and corresponding liner element distribution curves of the coatings on Mg/ $\beta$-TCP $+F S P-4$ deposited at $10 \mathrm{~mA} / \mathrm{cm}^{2}$ with $5 \mathrm{~min} \mathbf{a}, 15 \mathrm{~min} \mathbf{b}, 30 \mathrm{~min} \mathbf{c}$, respectively

$\mathrm{Mg} / \beta$-TCP FGMs show different corrosion behaviors and the goal of adjusting the degradation rate of $\mathrm{Mg}$ alloy bone implant materials can thus be realized.

After 30 min of deposition, the surface microstructure of the HA coating is uniform as shown in Fig. 11. It illustrates that the $\mathrm{Ca} / \mathrm{P}$ atomic ratio (1.17) of the $\mathrm{Ca}$ deficient HA coating is less than that of the bone (1.67), demonstrating the degradability of coating [37]. However, the contents of $\mathrm{P}$ and $\mathrm{Ca}$ indicate that the crystallinity of HA coating of $\mathrm{Mg} / \beta$-TCP FGM becomes denser and higher than the Mg-HA since the $\beta$-TCP is dispersed into the matrix, which are consistent with Figs. 8 and 9. The results indicate that the HA coating nucleates at the $\beta$-TCP (Fig. 5) on the grain boundaries grown up under the action of current. Compared with the PCL/HA coating of AZ/ HA-FHC sample prepared by Hanas et al. [33], the HA coating of $\mathrm{Mg} / \beta$-TCP FGM could protect the $\mathrm{Mg}$ matrix better because of its higher density. However, the biomineralization of the PCL/HA coating seems to protect the matrix again.
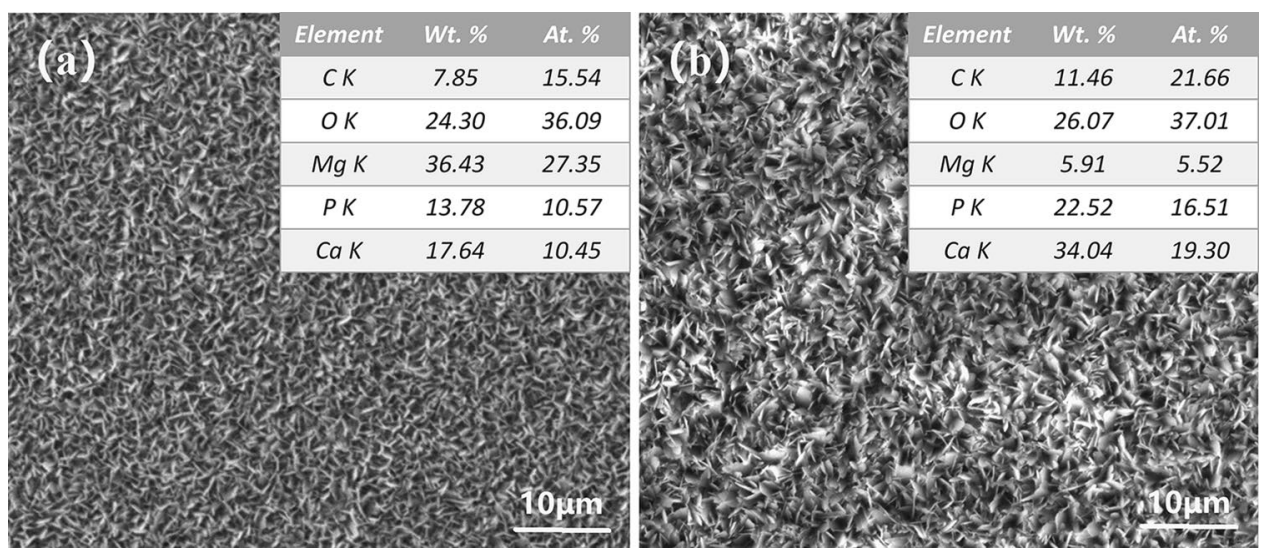

Fig. 11 SEM micrograph and EDS form of the coating of Mg-HA a, Mg/ $/$-TCP FGM b deposited at $10 \mathrm{~mA} / \mathrm{cm}^{2}$ with $30 \mathrm{~min}$ 


\subsection{Immersion performance}

Figure $12 \mathrm{a}$ indicates that the corrosion rate of $\mathrm{Mg} / \beta$ TCP FGM-30 $\mathrm{min}$ is $0.01411 \mathrm{mg} /\left(\mathrm{cm}^{2} \mathrm{~h}\right)$ after immersing for 14 days, which is the lowest compared to the $\mathrm{Mg} / \beta-\mathrm{TCP}+\mathrm{FSP}-4\left[0.07768 \mathrm{mg} /\left(\mathrm{cm}^{2} \mathrm{~h}\right)\right]$ and annealed $\mathrm{Mg}-2 \mathrm{Zn}-0.46 \mathrm{Y}-0.5 \mathrm{Nd}\left[0.11577 \mathrm{mg} /\left(\mathrm{cm}^{2} \mathrm{~h}\right)\right]$. The result is consistent with the degree of corrosion rate shown in Fig. 2. In Fig. $12 b$, the corrosion rate of $\mathrm{Mg} / \beta-\mathrm{TCP}$ FGM- $15 \mathrm{~min}$ and $\mathrm{Mg} / \beta$-TCP FGM- $5 \mathrm{~min}$ is $0.02300 \mathrm{mg} /\left(\mathrm{cm}^{2} \mathrm{~h}\right)$ and $0.02368 \mathrm{mg} /\left(\mathrm{cm}^{2} \mathrm{~h}\right)$ after 12 days, while that of $\mathrm{Mg} / \beta-\mathrm{TCP}$ FGM-30 $\mathrm{min}$ is $0.01632 \mathrm{mg} /\left(\mathrm{cm}^{2} \mathrm{~h}\right)$ as shown in Fig. 12a.

The corrosion morphology of annealed $\mathrm{Mg}-2 \mathrm{Zn}-0.46 \mathrm{Y}-0.5 \mathrm{Nd}$ and $\mathrm{Mg} / \beta-\mathrm{TCP}+\mathrm{FSP}-4$ immersed for 14 days in SBF is shown in Fig. 13. Large and deep corrosion pits appear on the surface of annealed $\mathrm{Mg}-2 \mathrm{Zn}-0.46 \mathrm{Y}-0.5 \mathrm{Nd}$. However, the $\mathrm{Mg} / \beta-\mathrm{TCP}+\mathrm{FSP}-4$ shows uniform cracks and tends to be uniformly corroded. The results are similar to those reported in the literature [26], indicating the additive could reduce the local degradation due to pitting. The main reason is that the grains of $\mathrm{Mg} / \beta$ TCP + FSP-4 are refined and the grain boundary energy became uniform to act as a barrier to retard the corrosion process [22].

Figure 14 shows that cracks appear in the coating in the early stage of corrosion. As the corrosion proceeded, the local coating appears to fall off. The main reason is that the corrosive liquid corrodes the matrix through the gap of the coating and hydrogen gas is generated to cause the coating to crack $[2,3,8]$. In Fig. 12b, the corrosion rate of the $\mathrm{Mg} / \beta$-TCP FGM- $5 \mathrm{~min} / \mathrm{Mg} / \beta$-TCP FGM- $15 \mathrm{~min}$ increases at $72 \mathrm{~h}$ and $96 \mathrm{~h}$, respectively. Figure 14b, e, h shows that local rupture appeared in the coatings at $168 \mathrm{~h}$, $96 \mathrm{~h}$ and $72 \mathrm{~h}$, respectively. In Table 3, the sudden increase
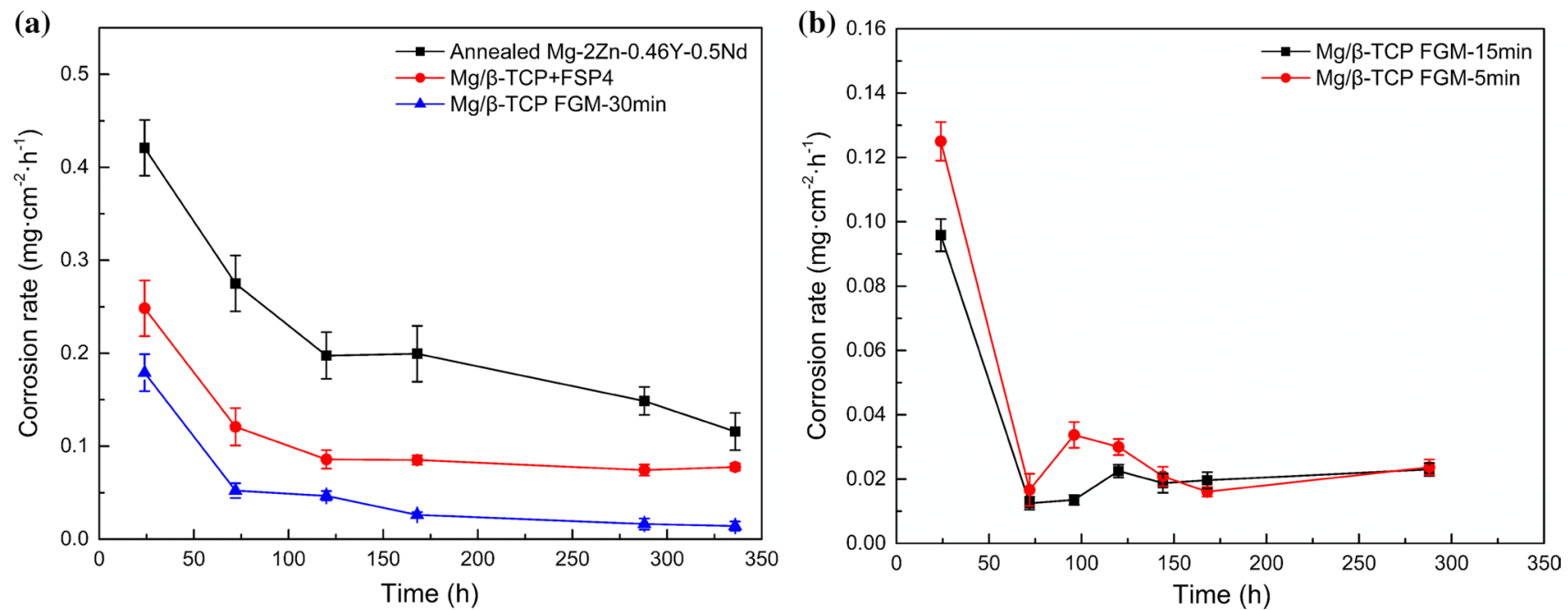

Fig. 12 Corrosion rate: a Mg alloy, $\mathrm{Mg} / \beta-\mathrm{TCP}$ and $\mathrm{Mg} / \beta-\mathrm{TCP}$ FGM-30 min immersed in SBF for 14 days; b Mg/ $\beta-\mathrm{TCP}$ FGM- 5 min $/ \mathrm{Mg} / \beta-\mathrm{TCP}$ FGM-15 min immersed in SBF for 12 days
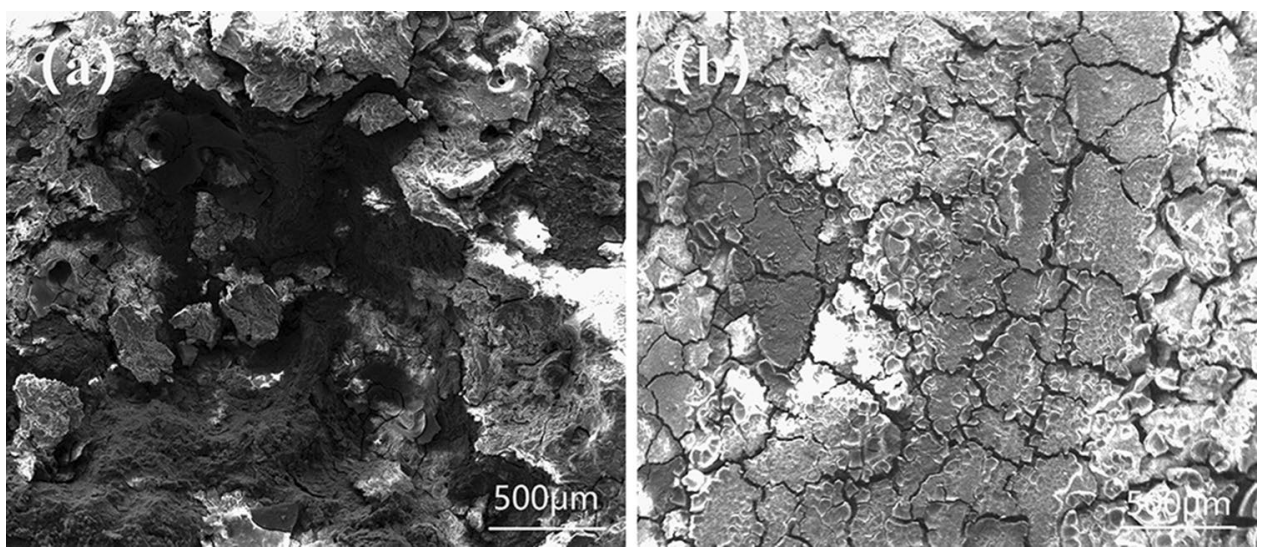

Fig. 13 Corrosion morphology immersed in SBF for $336 \mathrm{~h}$ : a annealed $\mathrm{Mg}-2 \mathrm{Zn}-0.46 \mathrm{Y}-0.5 \mathrm{Nd}$; b $\mathrm{Mg} / \beta-\mathrm{TCP}+\mathrm{FSP}-4$ 

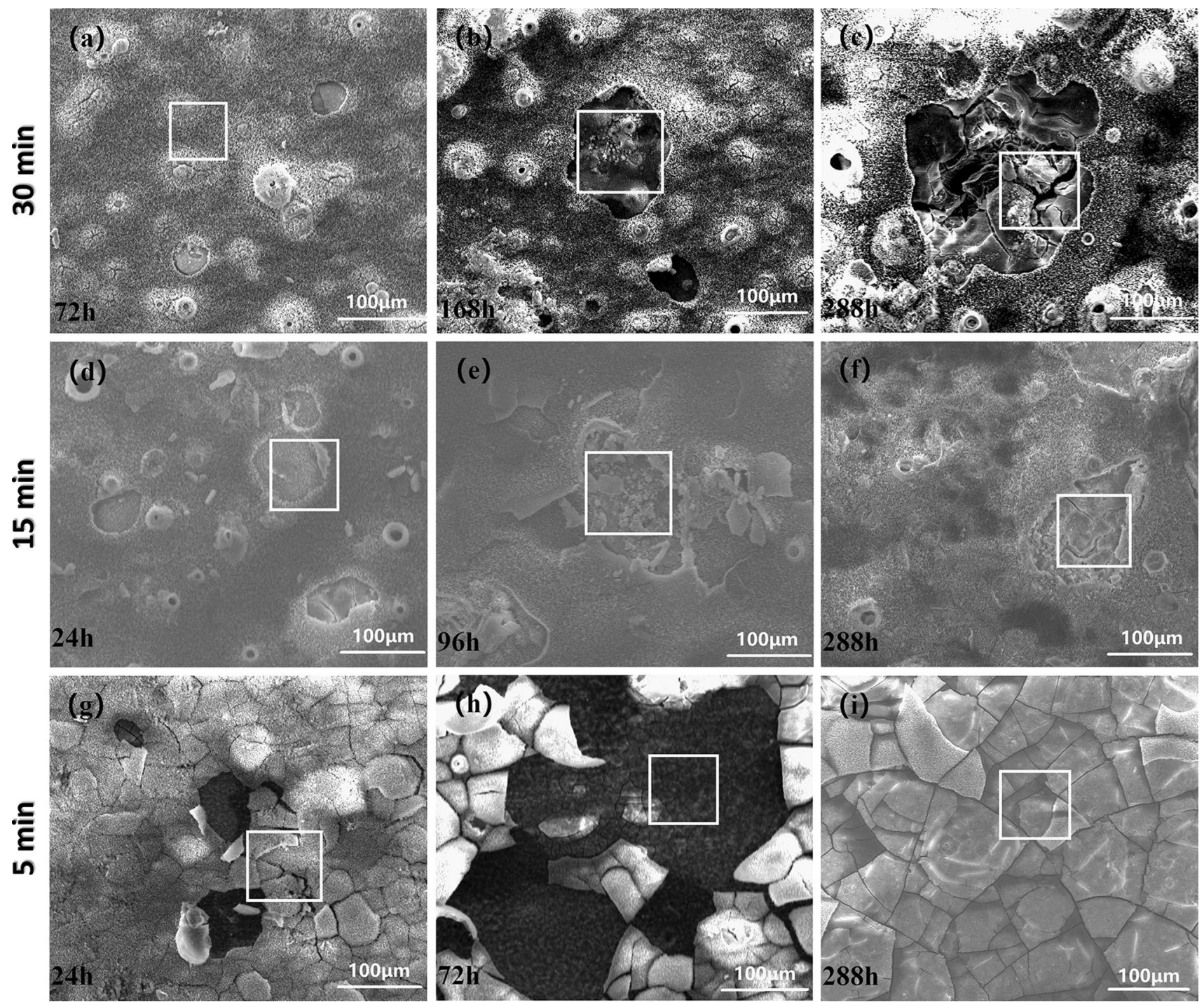

Fig. 14 Corrosion morphology of Mg/ $\beta$-TCP FGM-30 min immersed in SBF for $72 \mathrm{~h}$ a, $168 \mathrm{~h} \mathbf{b}, 288 \mathrm{~h} \mathrm{c}$; $\mathrm{Mg} / \beta-\mathrm{TCP}$ FGM-15 min for $24 \mathrm{~h}$ d, $96 \mathrm{~h} \mathbf{e}, 288 \mathrm{~h} \mathrm{f} ; \mathrm{Mg} / \beta-T C P$ FGM- $5 \mathrm{~min}$ for $24 \mathrm{~h} \mathrm{~g}, 72 \mathrm{~h} \mathrm{~h}, 288 \mathrm{~h} \mathbf{i}$; the area of white box is the place of EDS

Table 3 Element content of Mg/ $\beta$-TCP FGM in Fig. 13 white area (at.\%)

\begin{tabular}{|c|c|c|c|c|c|c|}
\hline & Time (h) & $\mathrm{C}$ & $\mathrm{O}$ & $\mathrm{Mg}$ & $\mathrm{P}$ & $\mathrm{Ca}$ \\
\hline \multirow{3}{*}{$\begin{array}{l}\mathrm{Mg} / \beta-\mathrm{TCP} \text { FGM- } \\
30 \mathrm{~min}\end{array}$} & 72 & 26.07 & 33.88 & 6.11 & 16.93 & 17.01 \\
\hline & 168 & 36.01 & 40.25 & 8.72 & 8.11 & 6.91 \\
\hline & 288 & 30.39 & 51.42 & 8.08 & 7.43 & 2.68 \\
\hline \multirow{3}{*}{$\begin{array}{l}\mathrm{Mg} / \beta-\mathrm{TCP} \text { FGM- } \\
15 \mathrm{~min}\end{array}$} & 24 & 23.28 & 36.84 & 14.89 & 11.99 & 11.66 \\
\hline & 96 & 24.36 & 39.69 & 29.40 & 3.23 & 1.49 \\
\hline & 288 & 25.20 & 45.98 & 6.32 & 10.39 & 9.96 \\
\hline \multirow{3}{*}{$\begin{array}{l}\mathrm{Mg} / \beta-\mathrm{TCP} \\
\text { FGM-5 min }\end{array}$} & 24 & 23.63 & 42.39 & 7.49 & 13.86 & 11.16 \\
\hline & 72 & 21.38 & 43.10 & 29.97 & 3.05 & 0.92 \\
\hline & 288 & 36.52 & 32.33 & 3.71 & 13.98 & 12.21 \\
\hline
\end{tabular}


in the $\mathrm{Mg}$ content corresponds to a drop in $\mathrm{Ca}$ and $\mathrm{P}$, which indicates a weakened ability of the coating to protect the $\mathrm{Mg} / \beta$-TCP from being corroded. The results indicate that the $\mathrm{Mg} / \beta$-TCP begins to be corroded and the coating loses its ability to protect the matrix. As shown in Table 3, the $\mathrm{P}$ and $\mathrm{Ca}$ contents increase after immersing in SBF for $288 \mathrm{~h}$, while the $\mathrm{Mg}$ content decreases since the $\mathrm{Mg} / \beta$ TCP is corroded to form Ca-P corrosion products on the surface [45]. The $\mathrm{P}$ and $\mathrm{Ca}$ contents of $\mathrm{Mg} / \beta$-TCP FGM30 min show the opposite variation trend probably because of the shedding of corrosion products.

Figure 14 and Table 3 provide that the effective protection time of the coating of $\mathrm{Mg} / \beta$-TCP FGM- $5 \mathrm{~min} / \mathrm{Mg} / \beta$ TCP FGM-15 min/Mg//-TCP FGM-30 min is $72 \mathrm{~h}, 96 \mathrm{~h}$ and $168 \mathrm{~h}$, respectively. After the coating fails, $\mathrm{Mg} / \beta$-TCP acts as a new protective layer to slow down the corrosion rate. The Mg/ $\beta$-TCP FGM behave in the form of layer-bylayer degradation, ultimately resulting in uniform corrosion and mechanical integrity. In short, it is a key factor to properly control the thickness and density of the coating for the clinical application of $\mathrm{Mg} / \beta$-TCP FGM as the bone implant material.

\section{Conclusions}

The mechanical property and corrosion behavior of the $\mathrm{Mg} / \beta$-TCP FGM after FSP and electrodeposition were evaluated in terms of the additive, microstructure and coating characteristics. Based on the above results, the conclusions are as follows:

1. By adding $\beta$-TCP in FSP-4 sample, a uniform finegrained structure can be obtained with an average grain size of $2 \mu \mathrm{m}$ and the average microhardness of $\mathrm{Mg} / \beta$ TCP is $76.3 \mathrm{HV}$.

2. The presence of $\beta$-TCP promotes the in situ growth of the HA coating. Compared to the bonding strength of $23.1 \pm 0.462 \mathrm{MPa}$ for the monolithic HA coating, the bond strength of the $\mathrm{Mg} / \beta-\mathrm{TCP}-\mathrm{HA}$ coating increases to $26.3 \pm 0.526 \mathrm{MPa}$ due to the reduced discontinuity of the coefficient of thermal expansion between the coating and the matrix.

3. The corrosion resistance of the $\mathrm{Mg} / \beta$-TCP FGM$30 \mathrm{~min}$ is greatly improved, and the corrosion rate is $0.01411 \mathrm{mg} /\left(\mathrm{cm}^{2} \mathrm{~h}\right)$ after 14 days.

4. Under a current density of $10 \mathrm{~mA} / \mathrm{cm}^{2}$ and a deposition time of $5 \mathrm{~min}, 15 \mathrm{~min}$ and $30 \mathrm{~min}$, the thickness of the HA coating is $3 \mu \mathrm{m}, 5 \mu \mathrm{m}$ and $9 \mu \mathrm{m}$, and the effective protection time is $72 \mathrm{~h}, 96 \mathrm{~h}$ and $168 \mathrm{~h}$, respectively.
Acknowledgements The authors are grateful for the financial support of the National Natural Science Foundation of China (No. U1804251) and the National Key Research and Development Program of China (Nos. 2018YFC1106703 and 2017YFB0702504).

\section{References}

[1] M. Song, R.C. Zeng, Y.F. Ding, R.W. Li, M. Easton, I. Cole, N. Birbilis, X.B. Chen, J. Mater. Sci. Technol. 35, 544 (2019)

[2] N. Li, Y. Zheng, J. Mater. Sci. Technol. 29, 502 (2013)

[3] S. Agarwal, J. Curtin, B. Duffy, S. Jaiswal, Mater. Sci. Eng. C 68, 963 (2016)

[4] M.P. Staiger, A.M. Pietak, J. Huadmai, G. Dias, Biomaterials 27, 1734 (2006)

[5] Y.F. Ding, R.W. Li, M. Nakai, T. Majumdar, D.H. Zhang, M. Niinomi, N. Birbilis, P.N. Smith, X.B. Chen, Adv. Healthc. Mater. 5, $1752(2016)$

[6] Y.F. Zheng, X.N. Gu, F. Witte, Mater. Sci. Eng. R 77, 34 (2014)

[7] F. Witte, V. Kaese, H. Haferkamp, E. Switzer, A. Meyer-Lindenberg, C.J. Wirth, H. Windhagen, Biomaterials 26, 3563 (2005)

[8] J. Bontrager, A. Mahapatro, A.S. Gomes, J. Microsc. 255, 115 (2014)

[9] S. Jafari, S.E. Harandi, R.K.S. Raman, JOM 67, 1153 (2015)

[10] W. Zhang, L.L. Tan, D.R. Ni, J.X. Chen, Y.C. Zhao, L. Liu, C.J. Shuai, K. Yang, A. Atrens, MCh. Zhao, J. Mater. Sci. Technol. 35, 783 (2019)

[11] T. Tokunaga, M. Ohno, K. Matsuura, J. Mater. Sci. Technol. 34, 68 (2018)

[12] Z.A. Luo, G.M. Xie, Z.Y. Ma, G.L. Wang, G.D. Wang, J. Mater. Sci. Technol. 29, 1122 (2013)

[13] C.Y. Liu, B. Qu, P. Xue, Z.Y. Ma, K. Luo, M.Z. Ma, R.P. Liu, J. Mater. Sci. Technol. 34, 112 (2018)

[14] R.Z. Xu, D.R. Ni, Q. Yang, C.Z. Liu, Z.Y. Ma, J. Mater. Sci. Technol. 32, 88 (2016)

[15] D.M. Sekban, S.M. Akterer, O. Saray, Z.Y. Ma, G. Purcek, J. Mater. Sci. Technol. 34, 237 (2018)

[16] W. Wang, R. Xu, Y. Hao, Q. Wang, L.L. Yu, Q.Y. Che, J.C. Cai, K. Wang, Z.Y. Ma, J. Mater. Sci. Technol. 34, 148 (2018)

[17] M. Saadatmand, J. Aghazadeh Mohandesi, Acta Metall. Sin. (Engl. Lett.) 28, 590 (2015)

[18] G.K. Padhy, C.S. Wu, S. Gao, J. Mater. Sci. Technol. 34, 38 (2018)

[19] G. Liu, L.N. Ma, Z.D. Ma, X.S. Fu, G.B. Wei, Y. Yang, T.C. Xu, W.D. Xie, X.D. Peng, Acta Metall. Sin. (Engl. Lett.) 31, 864 (2018)

[20] R.S. Mishra, Z.Y. Ma, Mater. Sci. Eng. R 50, 56 (2005)

[21] K.D. Ralston, N. Birbilis, Corrosion 66, 13 (2010)

[22] K.V. Kutniy, I.I. Papirov, M.A. Tikhonovsky, A.I. Pikalov, S.V. Sivtzov, L.A. Pirozhenko, V.S. Shokurov, V.A. Shkuropatenko, Mat.-wiss. u. Werkstofftech. 40, 246 (2009)

[23] L.L. Soon, H. Zuhailawati, I. Suhaina, B.K. Dhindaw, Acta Metall. Sin. (Engl. Lett.) 29, 474 (2016)

[24] M. Casas-Luna, S. Tkachenko, M. Horynová, L. Klakurkova, P. Gejdos, S. Diaz-de-la-Torre, L. Celko, J. Kaiser, E.B. Montufar, Acta Metall. Sin. (Engl. Lett.) 30, 325 (2017)

[25] K.K. Deng, C.J. Wang, K.B. Nie, X.J. Wang, Acta Metall. Sin. (Engl. Lett.) 32, 425 (2019)

[26] B. Ratna Sunil, T.S. Sampath Kumar, U. Chakkingal, V. Nandakumar, M. Doble, J. Mater. Sci. Mater. M 25, 988 (2014)

[27] B. Ratna Sunil, T.S. Sampath Kumar, U. Chakkingal, V. Nandakumar, M. Doble, V.D. Prasad, M. Raghunath, Mater. Sci. Eng. C 59, 367 (2016) 
[28] B. Rai, A. Chatterjea, Z.X.H. Lim, T.C. Tan, A.A. Sawyer, Y.Z. Hosaka, S. Murali, J.J.L. Lee, S.A. Fenwick, J.H. Huid, V. Nurcombe, S.M. Cool, Acta Biomater. 28, 204 (2015)

[29] L. Pang, Y.Y. Hu, Y.N. Yan, L. Liu, Z. Xiong, Y.Y. Wei, J.P. Bai, Surf. Coat. Technol. 201, 9557 (2007)

[30] J. Wang, L.G. Wang, S.K. Guan, S. Zhu, C. Ren, S. Hou, J. Mater. Sci. Mater. Med. 21, 2006 (2010)

[31] F. Witte, V. Kaese, H. Haferkamp, E. Switzer, A. Meyer-Lindenberg, C.J. Wirth, H. Windhagen, Biomaterials 26, 3563 (2005)

[32] H.S. Hedia, N.A. Mahmoud, Bio Med. Mater. Eng. 14, 143 (2004)

[33] T. Hanas, T.S.S. Kumar, G. Perumal, M. Doblec, S. Ramakrishnad, J. Mater. Process. Technol. 252, 406 (2018)

[34] C.Y. Li, X.L. Fan, R.C. Zeng, L.Y. Cui, S.Q. Li, F. Zh, Q.K. He, M.B. Kannan, H.W. Jiang, D.C. Chen, S.K. Guan, J. Mater. Sci. Technol. 35, 1098 (2019)

[35] H. Tang, Y. Han, T. Wu, W. Tao, X. Jian, Y.F. Wu, F.J. Xu, Appl. Surf. Sci. 400, 404 (2017)
[36] F. Marashi-Najafi, J. Khalil-Allafi, M.R. Etminanfar, R. FaeziAlivand, Mater. Corros. 68, 1245 (2017)

[37] H.X. Wang, S.K. Guan, X. Wang, C.X. Ren, L.G. Wang, Acta Biomater. 6, 1748 (2009)

[38] E.C. Meng, S.K. Guan, H.X. Wang, L.G. Wang, S.J. Zhu, J.H. Hu, C.X. Ren, J.H. Gao, Y.S. Feng, Appl. Surf. Sci. 257, 4814 (2011)

[39] R.W. Fonda, K.E. Knipling, Sci. Technol. Weld. Join. 16, 294 (2011)

[40] R.W. Fonda, J.F. Bingert, Scr. Mater. 57, 1055 (2007)

[41] J.Q. Su, T.W. Nelson, C.J. Sterling, Mater. Sci. Eng. A 405, 286 (2005)

[42] R.W. Fonda, J.F. Bingert, K.J. Colligan, Scr. Mater. 51, 248 (2004)

[43] Y.W. Song, D.Y. Shan, E.H. Han, Mater. Lett. 62, 3279 (2008)

[44] M. Jamesh, S. Kumar, T.S.N.S. Narayanan, J. Coat. Technol. Res. 9, $502(2012)$

[45] S. Agarwal, J. Curtin, B. Duffy, S. Jaiswal, Mater. Sci. Eng. C 68, 949 (2016) 